\title{
Systemic AA amyloidosis induced by liver cell adenoma
}

\author{
P Fievet, H Sevestre, M Boudjelal, L H Noel, F Kemeny, D Franco, J Delamarre, J P Capron
}

\begin{abstract}
Systemic AA amyloidosis is a rare complication of benign tumours. This report describes a patient with hepatocellular adenoma associated with reactive $\mathbf{A A}$ amyloidosis. He had a nephrotic syndrome with deteriorating renal function and an increase of serum concentrations of acute phase proteins, mainly Creactive protein. Resection of the tumour was followed by improvement in renal function and a marked decrease of the serum concentrations of acute phase proteins.
\end{abstract}

AA amyloidosis is usually observed during chronic infectious or inflammatory processes or of malignant neoplasia. ${ }^{1}$ The association of a benign tumour with localised and/or systemic AA amyloidosis has been rarely described. ${ }^{2-6} \mathrm{We}$ report the case of a man with systemic, mainly renal, AA amyloidosis induced by a liver cell adenoma. Surgical resection of the tumour was followed by an improvement in renal function and a decrease of the serum concentrations of acute phase proteins.

\section{Case report}

A 56 year old man was hospitalised for renal insufficiency with proteinuria. He had no previous history of inflammatory or infectious disease and had been treated for 10 years for essential hypertension (acebutolol) and for hypercholesterolaemia (ciprofibrate). $\mathrm{He}$ had never received androgens or oestrogens. Raised serum concentrations of gammaglutamyltrans-

Service de Néphrologie, Centre Hospitalier, Creil, France; the Service de Néphrologie, Hôpital Necker, Paris, France; the Service de Chirurgie Hépatobiliaire, Hôpital Paul Brousse, Villejuif,

France; and the Services d'Hépatogastro-

entérologie, d'Anatomopathologie et de

Radiologie A, Centre

Hospitalier, Universitaire

Nord, Amiens, France

$P$ Fievet

$\mathrm{H}$ Sevestre

M Boudjelal

L H Noel

F Kemeny

D Franco

J Delamarre

J P Capron

Correspondence to:

Dr J P Capron, Service

d'Hépato-gastroentérologie,

Centre Hospitalier

Universitaire Nord, Place

Victor Pauchet, 80030 Amiens

Cedex, France.

Accepted for publication

22 May 1989 ferase $(\gamma \mathrm{GT})$ had been noted for five years and related to alcohol abuse. Biochemical screening of renal function had been normal five years previously. The only clinical finding was a hepatomegaly measuring $12 \mathrm{~cm}$ on the midclavicular line. Laboratory evaluation disclosed the following: haemoglobin $15 \mathrm{~g} / \mathrm{dl}$; white blood cells $8950 / \mu$ l; erythrocyte sedimentation rate 68 $\mathrm{mm} / \mathrm{h}$; serum albumin, $26 \cdot 1 \mathrm{~g} / \mathrm{l}$; serum globulins, $18 \mathrm{~g} / \mathrm{l}$; serum fibrinogen $5 \cdot 2 \mathrm{~g} / \mathrm{l}$; serum C-reactive protein $23.8 \mathrm{mg} / 1$ (normal 2-12 mg/l); serum haptoglobin $3.7 \mathrm{~g} / \mathrm{l}$ (normal $1-3 \mathrm{~g} / \mathrm{l}$ ); blood urea $9.5 \mathrm{mmol} / \mathrm{l}$; serum creatinine $219 \mu \mathrm{mol} / 1$; serum alkaline phosphatase 207 IU/l (normal $<170$ ); serum $\gamma \mathrm{GT}, 140 \mathrm{IU} / \mathrm{l}($ normal $<20)$. There was a non-selective proteinuria of $2 \cdot 1 \mathrm{~g} / \mathrm{d}$.

Renal biopsy was performed and histological examination showed amyloid deposits in glomeruli, blood vessels, and to a lesser extent in the interstitium and tubular basal membranes. The birefringence of the deposits was sensitive to permanganate and the AA type of the amyloid substance was confirmed by immunohistochemical analysis using an anti-AA antiserum, as

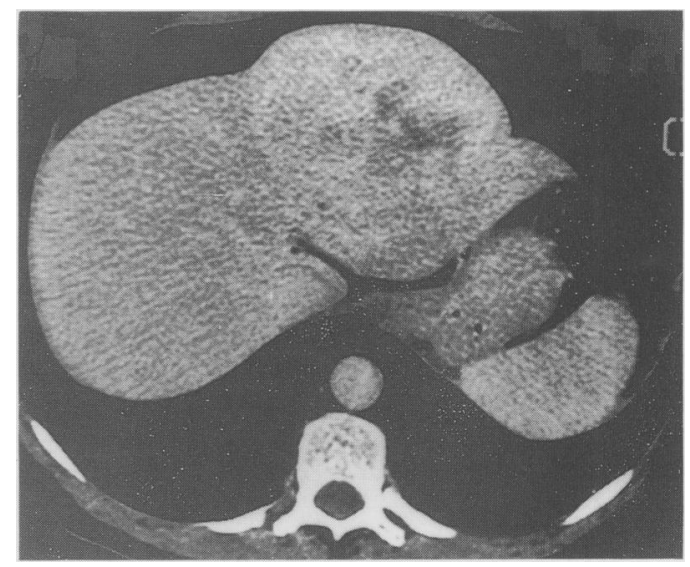

Figure 1: Hepatic computed tomography scan after contrast medium injection showed contrast enhancement of a tumour of the left lobe.

previously described. ${ }^{7}$ Ultrasound examination and abdominal computed tomography scan showed a large tumour in the left lobe of the liver (Fig 1). Ultrasound guided biopsy was performed in the tumour and the right lobe of the liver. Routinely processed samples showed amyloid deposits distorting liver cell plates in the tumour. In the right hepatic lobe, there were only vascular deposits. Amyloid substance was also present in duodenal, colonic and rectal mucosa.

Renal function rapidly deteriorated, and one month after the admission, blood urea and creatinine had reached $13 \cdot 1 \mathrm{mmol} / \mathrm{l}$ and 300 $\mu \mathrm{mol} / \mathrm{l}$, respectively. Hepatic left lateral lobectomy was performed without difficulty in haemostasis. Macroscopic examination showed a tumour measuring $11 \times 9 \times 4.5 \mathrm{~cm}$, with central areas of necrosis and haemorrhage. Histological examination of formalin fixed, Paraplast ${ }^{\circledR}$ embedded sections disclosed a mixture of voluminous pseudotumoural deposits of amyloid substance, liver cell plates dissociated by amyloid deposits, and some normal appearing plates (Figs 2 and 3). The amyloid heavily infiltrated the walls of the tumoural vessels. Congo-Red birefringence was markedly reduced by permanganate pretreatment; immunohistochemical studies gave positive results with antiAA antiserum. There was a sharp transition between the lesion and normal liver cell plates, without any intervening fibrous tissue. No bile duct nor terminal hepatic vein was identified in the lesion. The diagnosis of AA amyloid-secreting hepatocellular adenoma was considered. Radiographic and/or endoscopic examinations of thorax, kidneys, stomach, and colon, as well as the peroperative exploration of the abdominal cavity, did not find further neoplastic or inflammatory disease. Postoperative progress was uneventful, except for a slight increase of creatinine $(345 \mu \mathrm{mol} / \mathrm{l})$. One year later, renal 


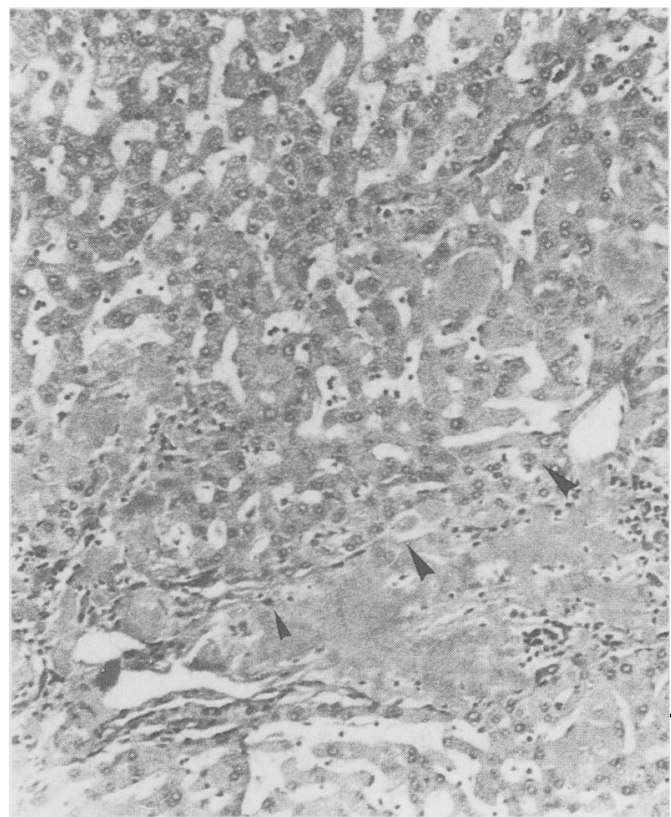

Figure 2: Amyloid adenoma of the liver. Massive deposits of amyloid in the tumour. Note the sharp transition between adenoma and normal liver (arrowheads) (HaematoxylinPhloxine-Safran).

insufficiency remained stable (urea, $9.9 \mathrm{mmol} / \mathrm{l}$; creatinine, $330 \mu \mathrm{mol} / \mathrm{l}$ ), proteinuria was $3.4 \mathrm{~g} / \mathrm{d}$. Biological markers of inflammation progressively returned to normal ranges: erythrocyte sedimentation rate, $40 \mathrm{~mm} / \mathrm{h}$; fibrinogen, $3.2 \mathrm{~g} / \mathrm{l}$; haptoglobin, $1.7 \mathrm{~g} / \mathrm{l}$; C-reactive protein, $2 \cdot 2 \mathrm{mg} / \mathrm{l}$.

\section{Discussion}

In this case, the following arguments suggest that AA amyloidosis was induced by the liver cell adenoma: (i) no other inflammatory, infectious or neoplastic cause of secondary amyloidosis could be detected; (ii) the most important deposition of amyloid substance was found within and around the adenoma; (iii) the initially increased serum concentrations of some acute phase proteins returned to normal range after surgical resection of the adenoma; this was especially evident for the C-reactive protein which is known to be closely correlated with the serum amyloid A protein, SAA ${ }^{8}$ SAA is the precursor of AA protein which is the main component of AA amyloid fibrils and it has been demonstrated in experimental models and in man that high serum concentrations of SAA play a key role in the deposition of amyloid substance ${ }^{9}{ }^{10}$; (iv) before surgery, renal insufficiency rapidly deteriorated, while it remained stable thereafter. In the case of Thysell et $a l^{2}$ a contraceptive induced hepatic adenoma was associated with systemic, particularly renal AA amyloidosis and proteinuria disappeared after surgical removal of the adenoma. In our patient, proteinuria persisted, but the kidneys were already severely damaged, whereas in Thysell's case renal function was normal.

Although synthesis of a RNA messenger specific to SAA has been observed in many tissues, synthesis of SAA has only been demonstrated in hepatocytes. ${ }^{12} 13$ Thus, the question

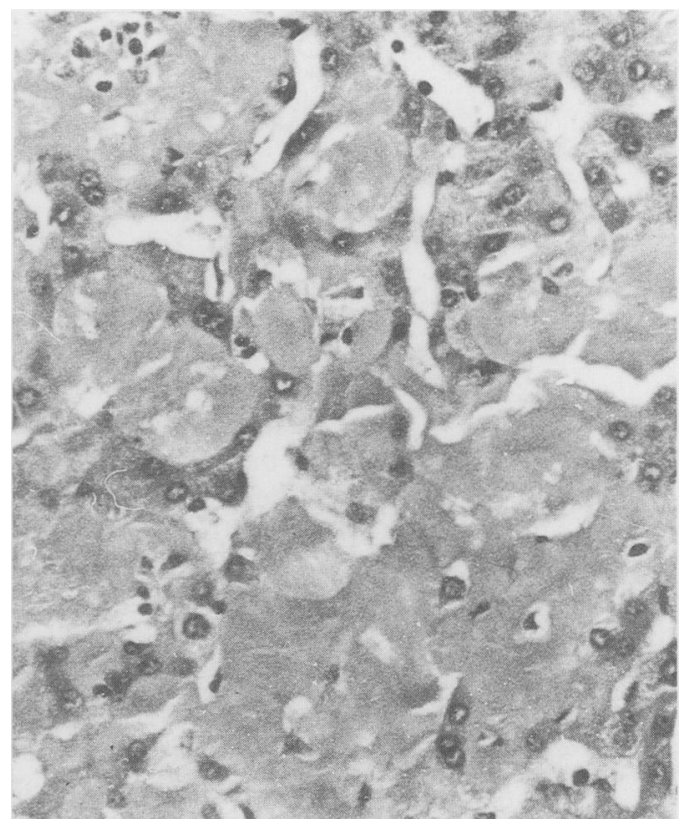

Figure 3: High-power view of amyloid deposits between liver cell plates in adenoma. (Haematoxylin-Phloxine-Safran).

may be raised whether such liver adenomas directly produce SAA or induce, through inflammatory or necrotic changes frequently observed in these tumours, ${ }^{14}$ synthesis of SAA under the influence of mediators such as interleukin-1. ${ }^{15}$ The first hypothesis is supported by the fact that amyloid deposits were abundant and predominant in the adenoma. Inflammatory processes were probably involved, however, as not only C-reactive protein, but other acute phase proteins, were increased before the surgical procedure and decreased after.

1 Pepys MB. Amyloidosis: some recent developments. Qf Med 1988; 67: 283-98.

2 Thysell H, Ingvar C, Gustafson T, Holmin T. Systemic reactive amyloidosis caused by hepatocellular adenoma. f Hepatol 1986; $2: 450-7$.

3 Larraza-Hernandez O, Albores-Saavedra J, Benavides G, Krause LG, Perez-Merizaldi JC, Ginzo A. Multiple endoKrause LG, Perez-Merizaldi JC, Ginzo A. Multiple endo-
crine neoplasia. Pituitary adenoma, multicentric papillary crine neoplasia. Pituitary adenoma, multicentric papillary
thyroid carcinoma, bilateral carotid body paraganglioma, thyroid carcinoma, bilateral carotid body paraganglioma, parathyroid hyperplasia, gastric leiomyoma an

4 Gelbard M, Johnson S. Primary amyloidosis of renal pelvis and renal cortical adenoma. Urology 1980; 15: 614-7.

5 Bogomoletz WV. Un adénome pléomorphe d'une glande salivaire avec dépôt de substance amyloïde. Arch Anat Pathol 1975; 23: 247-8

6 Wens R, Goffin Y, Pepys MB, et al. Left atrial myxoma associated with systemic AA amyloidosis. Arch Intern Med 1989; 149: 453-4.

7 Noel LH, Croz D, Ganeval D. Immunohistochemical characterization of renal amyloidosis. Am F Clin Pathol 1987; 87: 756-61.

8 Falk HM, Maury CPJ, Teppo AM, Wegelius O. Correlation of persistently high serum amyloid $\mathrm{A}$ protein and $\mathrm{C}$-reactive protein concentrations with rapid progression of secondary protein concentrations with rapid progres
amyloidosis. BrMed f 1983; 286: 1391-3.

9 Benditt EP. Amyloid protein AA and its precursor, the acute phase protein(s) ApoSAA: a perspective. In: Amyloidosis. Dordrecht: Martinus Nijhoff, 1986: 101-6.

10 Benson MD, Cohen AS. Serum amyloid A protein in amyloidosis, rheumatic, and neoplastic diseases. Arthritis Rheum $1979 ; 22: 36-42$

11 Ramadori G, Sipe JD, Colten HR. Expression and regulation of the murine serum amyloid A (SAA) gene in extrahepatic sites. F Immunol 1985; 135: 3645-7.

12 Benson MD, Kleiner E. Synthesis and secretion of serum amyloid protein AA (SAA) by hepatocytes in mice treated with casein. F Immunol 1980; 124: 495-9.

13 Pepys MB, Baltz ML. Acute phase proteins with special reference to $\mathrm{C}$-reactive protein and related proteins (pentaxins) and serum amyloid A protein. Adv Immunol 1983; 34: $141-211$. 
14 Kerlin P, Davis GL, McGill DB, Weiland LH, Adson MA, Sheedy PF, II. Hepatic adenoma and focal nodular hyperplasia: clinical, pathologic, and radiologic features. Gastroenterology 1983; 84: 994-1002.
15 Dinarello CA. Interleukin-1 and its effects on the liver. In: Arias IM, Jakoby WB, Popper H, Schachter D, Shafritz DA. The Liver: biology and pathobiology. New York: Raven Press, 1988: 897-905 